\title{
IS RECIPROCITY AN ENLIGHTENING CONCEPT TO ADDRESS CONTEMPORARY ISSUES?*
}

\author{
Ignasi Terradas \\ Universitat de Barcelona
}

ABSTRACT: If we want to use reciprocity as an enlightening concept to address contemporary issues, we have to deal with three problems: 1) The lack of consensus among anthropologists for an unique definition. 2) The great differences between an idea or practice of reciprocity primarily related to economics and those provided by relationships with other fields of social life. 3) The difficulty in dealing with reciprocity after the strong reinterpretations made by the ideology and practice of contracts in different societies.

First, I wish to answer straightforwardly to the question: it is enlightening indeed.

But together with this proposal we have to admit at least three problems.

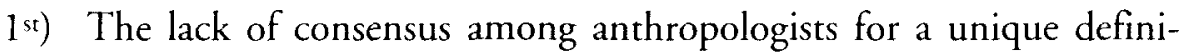
tion.

$2^{\text {nd }) ~ T h e ~ g r e a t ~ d i f f e r e n c e s ~ b e t w e e n ~ a n ~ i d e a ~ o r ~ p r a c t i c e ~ o f ~ r e c i p r o c i t y ~ p r i-~}$ marily related to economics and those provided by relationships with other fields of social life.

3 d) The difficulty in dealing with reciprocity after the strong reinterpretations made by the ideology and practice of contracts ${ }^{1}$ in different societies. This is a complex question to which I will refer only partially.

* Este artículo reproduce la comunicación presentada en el debate inaugural de ESF-SCSS Exploratory Workshop «Reciprocity as a Human Resource", Barcelona, septiembre 2001.

1 Coming from Roman, Common and Civil juridical traditions. 
Concerning the first problem I think that after so much criticism, we should take the most original and discrete definition of reciprocity we have. I am speaking of Marcel Mauss's statement on gift transmission. Although he does not relate systematically his idea of gift transmission with reciprocity, we understand as reciprocity the three phases of gift transmission: the duty or obligation to give, the duty or obligation to receive, and the duty or obligation to return. This, I suggest, could be described as the restricted notion of reciprocity or the gift system, that we will refer to as "strict reciprocity" ${ }^{2}$.

I think this notion of strict reciprocity is both useful and restricted. It is useful because it can be applied universally to different fields of social life. It is restricted because ethnographies show this reciprocity to cover less than the ideas and practices which constitute these social fields ${ }^{3}$. For instance, in a friendship or hospitality relationship there is a complex of sentiments, a-reciprocal initiatives, loose proposals, unconditional priorities, inviolability of the vinculum (bond), in fact all the life involved in the practical meanings of generosity, kindness, goodness, solidarity, love or simply shared time. All of it creates something much more elaborated than reciprocity. Something that may include reciprocity in its strict sense, but which is also more than anything understandable in terms of any type of reciprocity.

On the other hand, there is also a sort of hidden or ideological reciprocity in social occasions where human dealings are formalized in terms more simple than those of strict reciprocity. This is especially salient in the markets of collective unequal economies ${ }^{4}$, where exchange transactions appear to be mostly dependent on the things exchanged and on the economic power of people. Duties and obligations of reciprocity are here outside market pragmatics. In this sense we deem very appropriate Polanyi's distinction between reciprocity on the one hand and market economies and societies on the other.

2 This definition must admit the confusion between the gift system and reciprocity. That is to say: the three duties or obligations do properly entail the gift system and not necessarily the reciprocity relationship. But our priority is given to the fact that most of the world's ethnographic accounts inform of reciprocity in terms of the gift system.

3 Hospitality, friendship, kinship in marriage or burial, peace ceremonies, dispute settlements, blood brotherhood, ancestor vinculum, etc.

4 The category "collective unequal economy" is meant to cover all historical types of collective modes of production. 


\section{Reciprocity as a subsumed resource in the labour contract}

A crucial contemporary issue, which entails both the dimension of restricted reciprocity and that of lawful contract is the labour contract. This double dimension comes from liberal and conservative morals and ideologies rather than from the strict observance of capitalist relations. However, both Marxism and Business Economics do not consider all the values and duties which do operate inside business but are not made visible in the experiences exposed through accountancy, marketing and productivity data. Reciprocity introduces itself in business dealings, and particularly in labour contracts, through other means.

First, the presence of strict reciprocity is a result of the legal fiction of freedom of form and predetermined freedom in the inchoation (the making) of the contract. In other words, the labour contract's legitimacy is akin to that of a contract between property owners or capitalists: equality and equity before the market, the law and the society at large. However, the drive to contract is maintained by inequality and lack of equity: to take advantage from others needs, to be forced to sell or to buy, to be coerced to accept a type of employment and only a type of employment. Thus when the contract between business and labour is set (inchoate) there is already present a whole system of coercive behaviours. What I will contend is that strict reciprocity serves to shorten the distance between the legal fiction of the contract and the real lack of freedom to inchoate a contract in the objective terms it states. There is an as if which causes the transformation of a de facto position of dominance into one of legal equality: the businessman forced to sell or the worker forced to accept a deal, both behave legally as if they were not forced. The weight of this as if is counterbalanced by the assumption of a strict reciprocity scheme.

Lets recall the terms of a labour contract. First, in a contract ${ }^{5}$ generally, the covenant or pact is made over a matter or series of matters, which will tie the behaviour ${ }^{6}$ of the individuals under contract only regarding these matters. The pact does not rest upon a vinculum (bond) between persons ${ }^{7}$ concerning any matter that may involve them.

5 And this distinguishes properly the contract from the personal vinculum of reciprocity.

6 This behaviour equals the obligations on specified matters (under penal clauses if unaccomplished).

7 That will work in any event. 
Thus legal history presents two types of covenants, the contract where the notion of obligation goes as far as the matter involved in the contract, and the pact or alliance ad vinculis in which the obligation concerns anything that can happen to the persons involved ${ }^{8}$.

On the other hand the labour contract involves two juridical persons which contract two obligations: the supply of labour power to be arranged and conducted by the employer, and the retribution of this supply by means of a sum of money. But, the fulfilment of the labour contract has proven slim in providing all the human resources necessary to the demands of collective production. It is under this light that we propose the reconsideration of strict reciprocity as a human resource for the achievement of collective and unequal economic dealings.

Strict reciprocity involves duty and/or obligation in giving, accepting and returning. These actions are more than the actions of the contract: they involve stronger, sustained and outstanding human qualities. Also, the nature of these qualities is to create enduring personal bonds instead of discrete matters of contract. We are referring to personal bonds such as those in generosity, honour, responsibility, loyalty, sense of duty, kindness, and many others that refer to real practices in social fields, according to Japanese, and German, Catalan, Basque, Neapolitan or other backgrounds?

An important feature of populations affected by unequal collective economies is that the aspect of duty according to strict reciprocity compensates the starkness of obligation according to contract. In other words, strict reciprocity works as a set of moral duties rather than as a set of discrete legal obligations in unequal collective economies.

1) The employee's duty to give is: Interest in the work itself «uncontaminated" with the need and expectation of remuneration. Pride or identity with

8 This explains the discussion around the consideration of marriage as a contract over specified matters (such as those appearing in marriage tracts or compacts) or as a pact between persons for any matter. Marriage seems to have fluctuated between both types. Archaic and classical Roman law put the emphasis on the personal character of the vinculum, whereas canon law, and later civil law, established concrete matters but retained the language of the personal vinculum: "in health and illness... until death do us part" (Cf. Jean GAUDEMET (2000): Sociologie Historique du Droit, Paris: P.U.F).

9 My main experience on this field comes from the study of Industrial Colonies. Cf. Ignasi Terradas (1994): La qüestió de les Colonies Industrials, Manresa: Centre d'Estudis del Bages. 
the entrepreneur or the company, instead of pure market opportunity. Responsibility far beyond the material labour commitment, although exerted without legitimate authority. Display of energy, promptitude and altruistic service, but within the proxemics and subordination of the employee; etc.

2) The employee's duty to receive is: A moral acceptance of orders and discipline as a matter of fact of economic progress which justice must not interfere, especially if the firm is a "business with tendency» ${ }^{10}$. To take present and especially future remuneration as an effort made by the company to give, to be generous, to help, not as a retribution in due justice. To admit poor salaries, disgraceful work conditions and dismissal as mere accidents holding no relationship with the employers' responsibility or free will...

3) The employee's duty to return is: Loyalty and fidelity as if the employee is chosen not as a market opportunity (or by an already built patronage network) but as a social discovery achieved by worldwide experts. Extra responsibility and even friendship and gratefulness as market or patronage opportunities are ideologically transformed into gifts. People who have the power to «create» employment are considered givers of gifts. Politicians help the employees appreciate how pursuit of profit turns into a gift of labour positions, almost as a virtue of altruistic behaviour.

Thus, the employer's dury to give is ideologically ${ }^{11}$ constructed as a gift of labour. Also it is driven away from market reality and into the realm of human solidarity. The employer's gift is based in the transformation of the juridical person of the contract into a moral person with whom a bond of reciprocity is established. From the start the employer "offers" (supplies) instead of searching (demanding). Thus, people seeking work are constrained to see labour demand as supply created by a previous effort: investment (capital). Indeed, they do not appreciate that they are in demand in order to create the value that allows investment to appear in the market as wealth, and productive wealth moreover.

10 View promoted by the American Law and Economics ideology. This ideology consists basically in the laying of economic interests as dogmas of natural faith (- - like nineteenth century free- trade, laissez faire ideologists) and the posterior adjustment of law to these interests. Cf. a good criticism in Alain SUIJOT (2000): "The Dogmatic Foundations of the Market", Industrial Law Journal, 29,4.

11 I obviously deem better to say ideology or interest rather than culture. 
Even the neoclassical view where a real entrepreneur sells for an interest the use of machinery he has ordered to make (Walras), is superseded by the view where the businessman fights against all costs and market pressures (including taxes, of course) to create - to give - employment.

What does the employer think he receives from his employee? Here comes the bulk of reciprocity as performed by a moral person, for the employer reads the employee's compulsory drive from destitution as a freely chosen dedication and even a pleasure or honour to work with... or in...

The salary plays a minor role in the representation of the labour contract as reciprocity. Instead, the employer's return duty toward his employee is perceived as apprenticeship (in precarious employment), experience (in less precarious employment) and good retirement (in life employment). These are the goods given in return for the employee's dedication and loyalty.

What I think is very symptomatic of today's situation is that the juridical doctrine stresses the relevance of the moral personality (with exceedingly moral duties) of the employer much above his juridical personality (with material and discrete obligations). Thus, it is said that the employee has to consider as an honour his successful integration in the company and at the same time, the "tendency" of the business has the right to redefine and limit his social independence or right to intimacy ${ }^{12}$. While the former is a purely immaterial good, the latter is experienced through the concrete rule book of the business ${ }^{13}$.

According to Molero Manglano, labour relations do necessarily restrict the rights of honour and intimacy (of the employee, of course, who is never compared with his employer) ${ }^{14}$. He says that the labour relationship, more than any other, «implies the continuous acceptance of limits to the full exercise of

12 In several countries jurisprudence admits a great deal of independence from justice for the "business with tendency". The clearest case is for religious businesses. The jurisprudence of the French Supreme Court, among other courts, clearly accepts the rules of a religious order or fashion business to lay aside the non disposability of labor and human rights, provided that a moral consensus of the nation allows them without generating "social alarm». Thus, a fashion, sex or religious business enjoy a tolerance to implement offences against the right of intimacy as far as "public opinion" will allow. Cf. Vincente FORTIER (2000): Justice, Religion et Croyances, Paris: CNRS. Droit., p. 70 and f.

13 Cf. Carlos Molero Manglano (2001): «El derecho al honor y a la intimidad del trabajador", La Ley, 21. www.laley.net.

14 Id., op. cit., p. 4. 
personal rights ${ }^{15}$, especially those of honour and intimacy. The latter being particularly affected by the disciplinary power which the entrepreneur has by virtue of the labour order" ${ }^{16}$.

The Spanish Constitutional Court is eager to affirm that the labour contract generates «a reciprocal complex of rights and obligations which, together with others, impairs the exercise of law. In such a way, that the legitimate exercise of law in any other context does not necessarily occur in the context of the labour contract» 1 .

Molero Manglano underlines that the Spanish Constitutional Court admits the presence of loyalty and good faith (sic) in attitudes and conducts which are not addressed by the freedom and security of the person granted by the Constitution. 'Thus the old paternalism, deference and fidelity come again under these terms of loyalty and good faith. Moreover, the jurist explicitly confuses the moral and the juridical person of the employee (more than those of the employers!): "I believe it is dangerous to affirm forcefully that the worker does not have a duty of loyalty towards the firm, that his professional contribution in exchange for a salary does not morally vinculate him to the interest of the entrepreneur» ${ }^{18}$. Even though the jurist excludes serfdom and renunciation of fundamental human rights, there is a wide spectrum of influences, which seriously injure and impair the employee's freedom.

And what about the employer's loyalty towards the employee? . What about the difference of treatment accorded to conspiracies by managers in order to devaluate work and to dismiss workers ("re-structurations", «labour market flexibility») as opposed to those of workers to resist them ("losses»). Beyond that, few entrepreneurs get worried with loyalty when considering the future of their dismissed workers. More paradoxes arise when the economic fiction of equal opportunity is substituted by equity as a legal fiction ("positive discrimination»). Thus, Jean-Emmanuel Ray says : «Summum jus, summa injuria: prenant le législateur au mot, une enterprise a licencié en

15 If these personal rights are those of the juridical person, then the labour contract must observe them fully. Otherwise we are under a fiction: these personal rights are treated only partially as rights of the juridical person. The other part is under the umbrella of the private rule book of the business and the moral duties of the employee.

16 Molero Manglano. Id. I assume also that this order is the juridical ordination provided by labour laws and their procedures.

17 In 1983, 1985, 1990 and 1996 at least (Molero Manglano, op. cit., p. 5).

18 Id., p. 5. 
premier ses dix meilleurs salaries, leur indiquant que leur reclassement serait plus facile. La Cour de Toulouse n’a pas trouvé de cause réelle et sérieuse à ces ruptures, dont le caractère injuste avait sauté aux yeux des intéressés..." ${ }^{19}$.

Indeed, entrepreneurial knowledge about the worker's intimacy is very often felt as an offence. A subjective right begins with this appreciation and it can correspond to a subjective and objective right recognized in a legal code. The offence appears very clearly if roles are reversed. Thus, an employer would not like to be trusted or mistrusted according to his/hers sexual attitudes, club memberships, religion, family status, venereal diseases, genealogical and genetic "purity", etc. The jurist, however, also deems natural that the manager of human resources knows the income of every worker, whereas the reverse cannot be admitted because: "it can result very awkward indeed" (!) 20 . Also, the repression of strikers (through espionage) giving way to salary penalties or to dismissals is natural to the jurist, whereas the strike is accepted volens nolens as a «right" for the unloyal. Obviously, the jurist finds the courts biased in favour of workers demands ${ }^{21}$.

Anthropologists like Sally Falk Moore have recently stressed the increasing importance of the Law and Economics ideology in the USA, although with few feedback by anthropologists. She includes this ideology as an easy target for critics of law as domination 22 . In any case, the "new ideology» 23 would displace the question of contract and reciprocity, reducing it to a simple natural fact or law, which is less than reciprocity, for the view of the contract as a cultural construct merely stressing ${ }^{24}$ a simple natural law that of economic exchange- is much less than the strict concept of reciprocity. Then, for the Law and Economics ideology, there is no practice of reciprocity in the beginning of human society, but only the natural -constant- law of commodity exchange, something very "primitive" indeed,

19 J.-E. RaY (1997): "Le Chef Injuste» in De linjuste au juste. Paris: Dalloz.

20 Id., p. 9.

21 Although these opinions are not unique among jurists, I think they are the ones equivalent in Spain to the Law and Economics ideology.

22 Sally Falk MOORE (2001): "Certainties undone: fisty turbulent years of legal Anthropology, 1949-1999", Journal of the Royal Antbropological Institute, 7.

23 It is as old as the nineteenth century advocacy of free trade as Supiot clearly states.

24 SUPIOT (op. cit.) ironically argues that these radical economic neoliberals have brought up the Marxian theory of law as a superstructure of the economy convincingly. 
which has been now recuperated by American sophisticated lawyers and economists.

If reciprocity is often a hidden but pragmatic reality neighbouring contract, it is due to its human function: the universally felt need for something more trustworthy and easy than contract. Actually contract comes from mistrust and difficulty, whereas reciprocity is a duty felt or at fault. When duty and responsibility are at play, strict reciprocity gives an ease to common sense or plain human expectations that contract cannot provide. Thus, societies led by contracts necessarily do revivify strict reciprocity although in a hidden manner, which is no less effective however for the fulfilment of the clauses of a contract. 